D. J. Drewry: In most cases the dimensions of lakes are small (less than or comparable to ice thickness) so that the analogy with ice-shelf decoupling is not easy. Usually bottom crevasses on ice shelves are visible to radar sounding because frozen brine at the crack tip provides a strong dielectric contrast and a point reflector. Presumably non-saline water beneath the ice sheet might inhibit perception of crevasses at radar frequencies. Their absence in radar records, therefore, cannot be taken as proof that they do not exist.

R. H. Thомas: Presumably any melting or freezing that is taking place at the ice-sheet base will upset your calculations.

DREWRY: Naturally heat added or removed by freezing or melting at the interface has to be taken into account, but unless these zones are untypical of most glacier/ice-sheet beds the heat quantity will not be enormous (in the order of \pm 0.01 to $0.05 \mathrm{~W} \mathrm{~m}^{-2}$ ).

W. D. HARrison: Could one try the opposite approach, assume the heat flow, and estimate the freezing- or thawing-rate at the top of the lake?

Drewry: Certainly this inversion of the problem could be tried where we have a priori knowledge of the heat flux, say from bore-hole measurements into subjacent rock.

R. C. Metcalf: Often in my Caribbean work, one finds abnormal heat flow associated with tectonic activity (faulting) and geothermal activity. Are there indications of these processes in your studies of abnormal heat flow in the Antarctic?

Drewry: The investigated lakes lie close to the exposed Transantarctic Mountains and the McMurdo Cenezoic volcanic zone, with elevated heat flows. The possibility of a failed spreading axis in this region might also suggest enhanced geothermal activity. Lateral heat flushing induced by Australian-Antarctic plate separation is also a possible mechanism and it is interesting to note abnormally high heat flows are reported from south-eastern Australia (o.12 $\mathrm{W} \mathrm{m}^{-2}$ ).

\title{
OBSERVATION OF BASAL SLIDING OF VARIEGATED GLAGIER, ALASKA
}

\author{
By H. Engelhardt, B. Kamb, \\ (Division of Geological and Planetary Sciences, California Institute of Technology, Pasadena, \\ California 9 I 125 , U.S.A.) \\ C. F. RAymond, \\ (Geophysics Program, University of Washington, Seattle, Washington 98195, U.S.A.) \\ and W. D. HARRISON \\ (Geophysical Institute, University of Alaska, Fairbanks, Alaska 9970 I, U.S.A.)
}

Abstract. Variegated Glacier is a surge-type glacier in the St Elias mountain range in Alaska. The interval between surges is about 20 years; the last one occurred in 1964 to 1965 . This glacier has been studied extensively since 1973 (Bindschadler and others, 1977). Thus far, measurements of ice velocities have been restricted to the surface. They have been analyzed using geophysically measured ice depths, in order to estimate ice velocities in the ice mass and at the base (Bindschadler and others, 1978). From 1973 to 1977 the distribution of 
annual ice velocities along most of the length of the glacier can be explained primarily by internal deformation without major contribution from sliding at the base. However, the variation of surface velocity with time gives definite indication that sliding occurs in summer and that the average summer rate is increasing progressively from summer to summer and that in a zone 5 to $7 \mathrm{~km}$ below the head of the glacier the summer-to-summer increase in inferred sliding rate is especially rapid. This is a notably distinguishing feature, which is probably indicative of a build-up toward the next surge. In order to obtain direct information about sliding-rates and water pressures at the base in this zone, a bore hole was drilled to the bottom of the glacier about $6 \mathrm{~km}$ below the glacier head. Observations in the hole started in June 1978 and were continued until 31 July 1978 . The hole connected to an englacial water system at a depth of $204 \mathrm{~m}$ whereupon the water level dropped gradually to about $100 \mathrm{~m}$ below the surface. The last $6 \mathrm{~m}$ above the base at $356 \mathrm{~m}$ could be drilled only by means of a cable tool because of the presence of debris-rich ice. Upon reaching the bottom, the water level increased rapidly to the firn water table at about $8 \mathrm{~m}$ below surface. Large variations in water level of about $200 \mathrm{~m}$ occurred during the following period of observation of $35 \mathrm{~d}$. Major events such as audible icequakes, heavy rainfalls, and a period of unusually high ablation were associated with abrupt increases of water level up to the firn water table. High water pressure at the bottom drove a flow of muddy and sandy water upward in the hole. Consequently high freezing rates in the lower $150 \mathrm{~m}$ of the hole produced a very rough bore-hole wall covered with ledges, coral-reef-like features, grooves, and pockets filled with sand. Near the bottom, embedded rocks stuck out of the bore-hole wall. These features were recognized by bore-hole television. The bore-hole bottom consisted of sand which continuously proliferated and washed into the hole. Attempts to remove this sand by means of a sand pump failed, the bailed-out sand being replaced immediately. From bore-hole inclinometry an internal deformation of the ice mass of $0.22 \mathrm{~m} \mathrm{~d}^{-1}$ was obtained. Together with average surface velocity of $0.47 \mathrm{~m} \mathrm{~d}^{-1}$ we get a sliding velocity of $0.25 \mathrm{~m} \mathrm{~d}^{-1}$, averaged over the time of observation. This result confirms the sliding velocities inferred from surface velocity measurements. It also lies on the exponential trend line of increasing summer-to-summer velocities showing a doubling of sliding velocities about every two years (Bindschadler and others, unpublished). This strongly indicates that the next surge is likely to occur in the early eighties. Input of water from the surface probably will play a role in triggering the surge.

\section{REFERENCES}

Bindschadler, R. A., and others. 1977. Geometry and dynamics of a surge-type glacier, by R. [A.] Bindschadler, W. D. Harrison, C. F. Raymond, and R. Crosson. Journal of Glaciology, Vol. 18, No. 79, p. 181-94.

Bindschadler, R. A., and others. 1978. Sliding velocity of a surge-type glacier during its quiescent phase of motion, [by] R. [A.] Bindschadler, C. [F.] Raymond, and W. [D.] Harrison. Materialy Glyatsiologicheskikh Issledovaniy. Khronika. Obsuzhdeniya, Vyp. 32, p. 224-29.

Bindschadler, R. A., and others. Unpublished. Variegated Glacier studies 1976, by R. [A.] Bindschadler, W. D. Harrison, and C. F. Raymond. [Unpublished report available from any World Data Center: Glaciology.]

\section{BASAL SLIDING AND BED SEPARATION: IS THERE A GONNECTION?}

\section{By RoBert BINDSGHADLER}

(Geophysics Program, University of Washington, Seattle, Washington 98195, U.S.A.)

Abstract. Analysis of field data from Variegated Glacier supports the conclusion of Meier (1968) that no simple relationship between basal shear stress and sliding velocity can 